\title{
The effect of fermented coconut waste to the growth of catfish (ClariasSp)
}

\author{
Farizaldi $^{a *}$, Novirman Jamarun ${ }^{b}$, Jafrinur ${ }^{b}$, Yeti Marlida ${ }^{b}$ \\ ${ }^{a}$ Faculty of Animal Science University of Jambi, Jambi, Indonesia, 36361 \\ ${ }^{b}$ Faculty of Animal Science, Andalas University, Padang, West Sumatra, Indonesia, 25163
}

\section{A R T ICLE INFO}

Article history:

Received 4 March 2016

Revised 23 June 2016

Accepted 10 July 2016

Keywords:

Fermented

Coconut waste

Yeast bread

Catfish

\begin{abstract}
A B S T R A C T
This study aimed to determine the effect of fermented coconut waste on the growth of catfish (Clariassp). The study design used was completely randomized design (CRD) with 4 treatments and 5 replications. Treatments included P0 ( $0 \%$ of fermented coconut waste in the feed), P1 (10\% of fermented coconut waste in the feed), P2 (20\% of fermented coconut waste in feed), and P3 (30\% of fermented coconut waste in the feed). The observed variables were feed consumption, absolute body weight, feed conversion and survival rate. The results showed that using fermented coconut waste for catfish diet significantly $(P<0.05)$ affected feed intake, absolute body weight, feed conversion and live survival of the fish. The conclusion of this research was using $20 \%$ of fermented coconut waste in the diet can increase the growth of catfish (Clariassp).
\end{abstract}

\section{INTRODUCTION}

The development of fish farming in Indonesia often faces high feed cost, approximately 70 to $89 \%$ of total production costs, causing declining profit (Suprayudi, 2010). One attempt to increase the profit is to reduce the feed cost as minimal as possible; one way to do this is to explore the source of local feed ingredients that can be used as an alternative for fish feed. In selecting the local feed ingredients, several factors should be considered. Amongst others are: the availability of the materials, the cost, the content of nutrients, and the competition with humans (Handajani and Widodo, 2010). One alternative of the local feed ingredient in Indonesia that can be used to feed catfish is fermented coconut waste.

Coconut waste has considerable potential as alternative feed ingredients for fish feed. Coconut production in Indonesia, on average, reaches 15.5 million per year; that is equivalent to 3.02 million coconut meat per year. From every $100 \mathrm{~kg}$ of coconut meat, for manufacturing refined oils, $19.5 \mathrm{~kg}$ of coconut waste is produced (Aldimas et al, 2014). However, coconut waste has a weakness for animal feed, because it contains low crude protein and high crude fiber. This is evident in a study, which explains that the nutrient content of the coconut waste comprises $13.35 \%$ of water, $5.09 \%$ of crude protein, $9.44 \%$ of fat, $23.77 \%$ ofcarbohydrates, $5.92 \%$, ash, and $30.40 \%$ of rough fiber (Puri, 2011).

Crude fiber is a component of the feed material which is difficult to be digested by fish. The existence of this fraction will affect the digestibility and absorption of other nutrients, so that the protein in the feed cannot be used optimally for the formation of body tissues, which consequently disrupts livestock growth. To improve the nutritional content of coconut waste can be done through a yeast fermentation technology using local products such as tempe yeast, tape yeast and bread yeast. Because yeast contains microorganisms such as molds and bacteria as a fermentation starter, which is also rich in protein (around 40\%), which can break

*Corresponding email: fariz_nusa@yahoo.co.id 
down materials that cannot be digested (such as cellulose) into simple sugars that are easily digested with the help of enzyme synthesized by microorganisms (Parakkasi, 1990).Under these conditions, the study has been conducted to investigate the effect of coconut pulp fermented with local yeast for catfish (Clariassp) feed.

\section{RESEARCH METHODS}

\subsection{Research Material}

The experiment was conducted using a tarp aquarium and sample analysis at Laboratory Animal Nutrition Faculty of Animal Husbandry Jambi University for about 4 months. The research material used included coconut waste, corn, soybean meal, bran polishes, fish meal, fish oil, mineral mix, vitamin mix, bread yeast and catfish. While the equipment used included aquarium tarpaulin (size $100 \mathrm{~cm} \times 90 \mathrm{~cm}$ x 80 $\mathrm{cm}) \mathrm{pH}$ meter, thermometer, DO meter and laboratory equipment for sample analysis.

\subsection{Research procedure}

The study began with feed manufacturing of fermented coconut waste. The fermentation of coconut waste used bread yeast for 6 days. From fermented coconut waste, pellets for the research treatment were made. The nutritional content of constituents of the feed can be seen in Table 1, while the composition of the feed material and nutrient content of feed for the research treatment can be seen in Table 2. The catfish type used for the research was sangkuriang. The research used 16 units of tarp aquarium with 20 fish per aquarium. Before the first stocked fish were weighed and measured to determine the length of the initial weight and length of the fish early. All of all the fish was weighed and measured and before the treatment. In addition, the fish were also acclimatized to adapt the new environment. The feeding treatment given was $5 \%$ of the fish weight (biomass) with the frequency of three times a day at 08:00 am, 1:00pm and 5:00 pm. The fish were weighed and their lengths were measured to identify their growth. Based on such data, the next treatment or feed consumption for the next period was planned

Table 1. Nutrition Content for Feed materials Research Treatment.

\begin{tabular}{|c|c|c|c|c|c|c|c|}
\hline \multirow[b]{2}{*}{ Feed material } & \multirow{2}{*}{$\begin{array}{c}\text { Gross } \\
\text { Energy } \\
(\mathrm{kkal} / \mathrm{kg})\end{array}$} & \multicolumn{6}{|c|}{ Feed Nutrition $(\%)$} \\
\hline & & $\begin{array}{l}\text { Crude } \\
\text { Protein }\end{array}$ & $\begin{array}{c}\text { Crude } \\
\text { Fat }\end{array}$ & $\begin{array}{l}\text { Crude } \\
\text { Fiber }\end{array}$ & Ash & Calcium & Phosphor \\
\hline $\begin{array}{l}\text { Fermentation 1) } \\
\text { Coconut Waste }\end{array}$ & 5140.67 & 20.23 & 8.00 & 5.00 & 2.62 & 0.30 & 1.91 \\
\hline $\begin{array}{ll}\text { Corn } & \text { 2) }\end{array}$ & 4425.00 & 9.50 & 2.54 & 2.06 & 3.51 & 0.20 & 0.28 \\
\hline $\begin{array}{ll}\text { Bran Polishes } & \text { 2) }\end{array}$ & 3315,00 & 10.90 & 7.51 & 13.05 & 10.51 & 0,20 & 1,20 \\
\hline Soybean Meal & 3918.00 & 46.55 & 1.91 & 4.96 & 8.16 & 0.50 & 0.54 \\
\hline Fish Meal & 4097.00 & 52.60 & 3.78 & 5.02 & 25.98 & 10.60 & 4.64 \\
\hline Fish Oil & 902.00 & 3.70 & 70.40 & 0.75 & - & - & - \\
\hline Premix & - & - & - & - & - & 5.38 & 1.14 \\
\hline
\end{tabular}

1) Analysis Laboratory of Non Ruminant Faculty of Animal Science Univ of Andalas, 2014

2) Analysis Laboratory of Animal Nutrition Faculty of Animal of Science Univ. of Jambi (2013)

(Agustine, 2009).

The experimental design used was complete randomized design (CRD) with 4 treatments and 4 repetitions, so there were 24 experimental units. The treatment used was of four kinds: the feed without fermented coconut waste (P0); the feed containing $10 \%$ of coconut fermentation waste (P1); the feed containing $20 \%$ of coconut fermentation waste (P2); and the feed containing $30 \%$ of coconut fermentation waste (P3).

The variables observed were the amount of feed consumed, absolute body weight growth, feed conversion, and survival rate. The data were analyzed by the analysis of variance, and to compare the four treatments, Duncan's multiple 
advanced tests were used (Steel and Torrie, 1989).

\section{RESULTS AND DISCUSSION}

The average value of feed consumption, the absolute body weight, feed conversion and survival rate of various treatments during the study are seen in the Table 3 .

Table 2.Composition of Feed Materials and Feed Nutrition Research Treatment

\begin{tabular}{lrrrr}
\hline \multirow{2}{*}{ Material Feed } & \multicolumn{2}{c}{ Feed Treatment } & & \\
\cline { 2 - 6 } & P0 & P1 & P2 & \\
\hline Fermentation coconut waste (\%) & 0 & 10 & 20 & 30 \\
Corn (\%) & 10 & 8 & 6 & 4 \\
Bran Polishes (\%) & 38 & 32 & 27 & 22 \\
Soybean Meal (\%) & 20 & 19 & 17 & 15 \\
Fish Meal (\%) & 30 & 29 & 28 & 27 \\
Tapiocal (\%) & 0.50 & 0.50 & 0.50 & 0.50 \\
Fish Oil (\%) & 1 & 1 & 1 & 1 \\
Premix (\%) & 0.50 & 0.50 & 050 & 0.50 \\
Total & $\mathbf{1 0 0}$ & $\mathbf{1 0 0}$ & $\mathbf{1 0 0}$ & $\mathbf{1 0 0}$ \\
CrudeProtein (\%) & 32.24 & 32.40 & 32.22 & 32.05 \\
Crude Fat (\%) & 6.62 & 6.86 & 6.16 & 6.46 \\
Crude Fiber (\%) & 7.66 & 7.24 & 6.89 & 6.09 \\
Ash (\%) & 13.77 & 12.99 & 12.23 & 11.47 \\
Calcium (\%) & 3.38 & 3.28 & 3.18 & 3.08 \\
Fosfor (\%) & 1.98 & 2.05 & 2.11 & 2.18 \\
Gross Energi (kkal/kg) & 3714.90 & 3861.41 & 4001.90 & 4142.39 \\
\hline
\end{tabular}

Table 3. Feed Consumption, Absolute Body Weight, Feed Conversion and Survival Rate at Treatment for 2 months of The Research

\begin{tabular}{llllll}
\hline \multirow{2}{*}{\multicolumn{1}{c}{ Parameters }} & \multicolumn{5}{c}{ Treatment } \\
\cline { 2 - 5 } & \multicolumn{1}{c}{$\mathrm{P} 0(0 \%)$} & $\mathrm{P} 1(10 \%)$ & $\mathrm{P} 2(20 \%)$ & $\mathrm{P} 3(30 \%)$ \\
\hline Feed Consumption (g/fish) & $115,74 \mathrm{~b}$ & $116,79 \mathrm{~b}$ & $118,18 \mathrm{~b}$ & $122,09 \mathrm{a}$ \\
Absolute Body Weigh (g/fish) & $71,87 \mathrm{~d}$ & $79,06 \mathrm{c}$ & $94,35 \mathrm{a}$ & $80,47 \mathrm{bc}$ \\
Feed Conversion & $1,06 \mathrm{a}$ & $0,98 \mathrm{~b}$ & $0,90 \mathrm{c}$ & $1,02 \mathrm{ab}$ \\
Survival Rate (\%) & $88,89 \mathrm{~b}$ & $91,66 \mathrm{ab}$ & $94,44 \mathrm{a}$ & $93,05 \mathrm{a}$ \\
\hline
\end{tabular}

Description: Lowercase different on the same line indicate significantly different $(\mathrm{P}<0.05)$

\subsection{Feed consumption}

The variance analysis showed that the treatment using fermented coconut waste significantly affected $(\mathrm{P}<0.05)$ the amount of feed consumption. This indicates that providing fermented coconut waste up to $30 \%$ in the diet can increase the amount of catfish consumption. The multiple Duncan advanced test showed that the treatment P3 (using $30 \%$ fermented coconut waste) resulted $122.09 \mathrm{gr}$, which was higher (P $<0.05$ ) than the P2 treatment (using $20 \%$ fermented coconut waste) resulted $118.18 \mathrm{gr}$; the treatment P1 (using 10\% gram of fermented coconut waste) resulted $116.79 \mathrm{gr}$; and P0 (without coconut waste fermentation) resulted 115.74 gr. However, the treatment P2 (using 20 $\%$ fermented coconut waste) had no significant difference $(\mathrm{P}>0.05)$, which was relatively equal compared to the treatment P1 (using 10\% fermented coconut waste) and the treatment P0 (without coconut waste fermentation).

Table 3 shows that the more fermented coconut waste in the feed the higher the feed intake. This means that the higher the concentration of the fermented coconut waste in feed the higher the palatability of the fish toward the feed. This condition is caused by the aroma 
and delicious taste of the fermented coconut waste made using the bakery yeast, so that the appetite of fish to consume increases. Poesponegoro (1975) and Karmini (1996) argued that fermentation process may increase nutrition quality such as the protein content, fats and flavors that usually can stimulate palatability. Inara (2011) also states that palatability may be influenced by the feed shape, size, color, flavor and aroma.

Besides palatability, the increase of the feed consumption is also caused by the decreasing crude fiber content in the feed such as shown in using fermented coconut waste as shown in Table 2. The decrease of crude fiber content was caused by the enzyme synthesized by microorganisms found in fermented coconut waste, which can degrade crude fiber that is difficult to be digested into to easily digested in the gastrointestinal tract. The faster the nutrients are digested in the gastrointestinal tract of fish, the more the feed can be consumed. Andhikawati et al (2014) argue that the mold can synthesize enzyme cellulose, which serves to break down cellulose into simple carbon sources. Rakhmawati and Indariyanti (2013) added that the aspergillusniger fermentation process will produce enzyme amilotik, proteolytic and lipolytic, thus the quality of agricultural waste can be better; and enzymes xylanase and cellulose can also lower crude fiber content, which is fermented feed materials. When the crude fiber is low, the nutrient content of feed digestion process will be easier.

\subsection{Absolute Body Weight.}

Analysis of variance showed that the administration of the treatment of fermented coconut waste significantly affected $(\mathrm{P}<0.05)$ the growth of the absolute body weight. This is caused by the amount of feed intake, which is also influenced significantly $(\mathrm{P}<0.05)$ by administration of fermented coconut waste. If the amount of the consumed feed is high, then the amount of substances consumed is high too. This positively affected the growth rate of the fish efficiently, which increased fish production. Arlia (1994) suggest that a better body growth will occur only when the amount of feed consumed the fish is greater than the required and the amount of nutrients containing in the feed given.
The treatment of fermented coconut waste, which significantly affected $(\mathrm{P}<0.05)$ on the growth of absolute weight could also be caused by the good feed composition and the balance of nutrients content in the treatment which has met the needs of the fish. Halver (1989) stated that the balancing and complete nutrients (required by the fish), beside can increase the speed of growth, they also can balance the effects of pressure (physiology) and restrictions of fish movement. Cahyono (2001) added that if the sufficiency and quality of feed and good environmental conditions support the growth rate. Conversely, the in sufficiency and the poor feed quality as well as bad environmental conditions can cause negative effect to the growth rate.

Multiple Duncan advanced test showed that the effect of the treatment P2 (20\% fermented coconut waste) with absolute body weight of $94.35 \mathrm{~g} /$ fish is significantly different $(\mathrm{P}<0.05)$ which is higher than the result of the treatment $\mathrm{P} 0$ (without coconut waste fermentation) which is $71.87 \mathrm{~g} / \mathrm{fish}$, higher than the result of the treatment P1 (10\% coconut waste fermentation) which is $79.06 \mathrm{~g} /$ fish, and higher than the result of the treatment P3 (30\% coconut waste fermentation), which is $80.47 \mathrm{~g} /$ fish. The result of the treatment P3 was not significantly different $(\mathrm{P}>0.05)$, which is relatively the same as the result of the treatment $\mathrm{P} 1$, and is significantly different $(\mathrm{P}<0.05)$, which is higher than the result of the treatment $\mathrm{P} 0$; whereas the result of the treatment $\mathrm{P} 1$ is significantly different $(\mathrm{P}<0.05)$, which is higher than the result of the treatment $\mathrm{P} 0$.

The highest absolute growth body weight was obtained in the treatment P2, namely 94.35 g/fish. This shows the optimum content of percentage of fermented coconut waste for fish feed. This means that the percentage of the substance that can be digested and absorbed in the gastrointestinal fish digestive tract (especially protein, fat and carbohydrates) containing in the treatment already exceed the required needs for the fish to live and for their activities. The excessive nutrients are stored in the form of energy. The energy used to synthesize cell components resulting in increasing cell, both in number and size, which will lead to an increase in the volume of tissue, which would be followed by muscles growth and 
organs. Amalia et.al (2013) stated that growth occurs when there is an excess of energy, after the energy is used for maintenance of the body, basal metabolism and activity. Brett and Groves (1979) argued that growth will occur because of the excess energy that comes from the feed after deducting excretion and metabolism as well as the activity.

Table 3 shows the increasing contents of the fermented coconut wastein the feed affects the growth in absolute body weight of the fish, but at the level of percentage of $(30 \%)$ as shown in the treatment P3, the absolute body growth decreased, but the result is still higher than the control diet treatment (without the fermented coconut waste). Such decline in growth of absolute body weight is caused by the maximum provision of fermented coconut waste in fish feed. The maximum provision of fermented coconut waste in the feed can cause high content of mannan and glucomanan, which can lead into anti-nutrients problems as these substances can lead to the ineffective work of enzyme in the digestive tract, making it difficult to digest food substances, and the reduction of nutrients absorbed by the body results in stunted growth. Francis et.al (2001) suggest that using too high percentage of coconut waste fermentation resulted decreasing growth of the absolute body weight. Coconut waste contains mannan and glucomannan, which include in non-starch polysacharida (NSP) as anti-nutrients in feed, and NSP is bound in water and forms a kind of gum, resulting the material viscosity in the gut, which blocks the digestive enzyme activity that will suppress the growth of livestock.

\subsection{Feed conversion}

The value of feed conversion shows the performance of livestock in feed use. The higher the value, the higher the feed consumption needed to promote body weight, and vice versa the lower the value, the more efficient the feed consumption to produce body weight.

The result of the treatment analysis shows that using the fermented coconut waste in the feed had significant effect $(\mathrm{P}<0.05)$ on feed conversion. This is in line with the amount of feed intake, and the growth of absolute body weight was also affected significantly $(\mathrm{P}<0.05)$ by the treatment of the fermented coconut waste.
Therefore, the ratio of feed consumption and growth of absolute body weight showed significantly different results too. Rasyaf (1989) argued that the amount of feed conversion is determined by the amount of feed intake and the absolute body weight gained. Murtati (1989) added that the value of the feed conversion is not only determined by the amount of feed given, but also influenced by several factors such as density, weight of the individual, age of the animal, the water temperature of media, and the way of feeding.

Based on the advanced multiple Duncan testing, it was seen that the treatment P0 had the highest feed conversion (1.06), but it was not significantly different $(\mathrm{P}>0.05)$ with treatment P3. The lowest feed conversion was shown by the treatment P2 (0.90), which is significantly different $(\mathrm{P}<0.05), \mathrm{P} 1$ is 0.98 , and $\mathrm{P} 3$ is 1.02 , and $\mathrm{P} 0$ is 1.06 .

The highest feed conversion is shown by the treatment $\mathrm{P} 0$, because the growth of body weight of catfish is not balanced with the amount of feed intake. Thus, the treatment P0 is the least efficient to be used as feed to produce $1 \mathrm{~kg}$ of body weight of cattle catfish. Effendie(1979) stated that the feed conversion ratio is a measure of the amount of feed needed to produce $1 \mathrm{~kg}$ of culture fish. The lower the value of feed conversion the least the feed needed to produce $1 \mathrm{~kg}$ fish. Yurnita (2004) added that the feed intake is closely related to nutrients in the feed; the feed consumption increases when the protein content in the feed, the body weight increases and the rate of feed conversion also increases.

\subsection{Survival Rate}

The survival rate is the number of fish that can survive for living beginning from seeding to harvesting (Effrendie and Hadiroseyani (2002).

The analysis of variance showed that the treatment used in this research significantly ( $P$ $<0.05$ ) affect the survival rate of catfish, meaning that giving fermented coconut waste can reduce mortality rate (the number of dead fish). This can also mean that the amount and the nutrient content of the feed given meet the needs of fish for activity, growth and survival. Kordi, (2010) argues that the level of survival rate of a cultivation biota is influenced by several factors, one of which is feed nutrients. It has been argued 
that fats can affect taste and texture of feed, but excessive fat content in feed, will affect the quality, which is susceptible to oxidation, and contributes rancid odor. Fish consuming too much fat will have accumulation of fat in the walls of abdominal cavity and intestine, causing symptoms of liver lipid degeneration (LLD), contributing to kidney problems, edema, and anemia that causes death. Survival rate of fish is also determined by environmental conditions such as adequacy of water for growth and development, the appropriate average of water temperature (ranging from $26.8^{\circ} \mathrm{C}$ to $28.7^{\circ} \mathrm{C}$ ), water $\mathrm{pH}$ (ranging from 6.4 to 7.1), and DO (3.5$4.4 \mathrm{mg} / \mathrm{l}$ ). Khairuman and Amri (2011) argue that a suitable temperature for the African catfish is $20^{\circ} \mathrm{C}-30^{\circ} \mathrm{C}$, dissolved oxygen content in the water is at least at $3.5-6 \mathrm{ppm}$ (milligrams per liter), and the degree of acidity (pH) is 6-8.

In this study, Duncan's Multiple test shows that the highest survival rate was obtained in the P2 treatment (20\% of fermented coconut waste), which was $94.44 \%$, significantly (P different $<0.05$ ) from P0 treatment (without coconut waste fermentation), which was $88.89 \%$; but not significantly different $(\mathrm{P}>0.05)$ or relatively similar to $\mathrm{P} 1$ treatment $(10 \%$ fermented coconut waste), which is $91.66 \%$, and the P3 treatment $(30 \%$ fermented coconut waste), which is $93.05 \%$.

Table 3 shows that the higher the content of coconut waste in feed, the higher the survival rate of fish. This proves that the addition of

\section{REFERENCES}

Aguntine, L.N. 2007. Fish Oil Supplements In Goat Rations Its Influence On The Digestibility Of Dry Materials And Organic Ingredients Invivo. (Essay). Faculty of Animal Science General Sudirman, Purwokerto.

Aldimas, T. P ,. Great, A.W, Chairul, A ,. Dian, A.R ,. Hasrul, A. 2014. Potential Waste Dregs Coconut (Cocosnucifera) As Flour Substitute Products Mococo (Modified Coconut Cookies). PKM report Bogor Agricultural University.

Andhikawati A., Oktavia.Y, Ibrahim B., Tarman K. 2014. Isolation And Screening Of Endophytic Marine Fungi For Cellulase Production. Journal of Science and Tropical Marine Technology. 6: 219-227.

Amalia, R., Subandiyono, and E. Arini. 2013. The effect of dietary protein on papain utility and growth of African catfish

\footnotetext{
*Corresponding email: fariz_nusa@yahoo.co.id
}

fermented coconut waste in feed affect the level survival rate of catfish, and the mortality rate declines. Veni (2007) argued that the high mortality is caused by inappropriate environmental factors, the unavailability of food, and physical damage resulting from careless handling of fish.

The survival rate of African catfish ranges between $88.89 \%$ and $94.44 \%$ which is relatively high. Suyanto (2007) argues that the mortality rate that reaches $30-50 \%$ is considered normal, and in general, the death of catfish occurs after observation, e.g., after measuring the length and weight of the fish.

\section{CONCLUSION}

Coconut waste in quantity is quite potential as one source of feed ingredients, but the nutritional content is still not fulfilling the needs of fish, so it needs to be increased nutritional content, one of them through fermentation technology with yeast bread.

Based on the results of this study it can be concluded that the provision of coconut fermentation with bread yeast up to30\% level in the feed can increase feed consumption, absolute body weight and survival and can decrease the feed conversion in catfish. The best growth in catfish is obtained at the level of $20 \%$ of the fermented coconut dregs with the yeast of bread in fish feed.

(Clariasgariepenus). J.aquaculture management and technology, 2 (1): 136-143.

Arlia L. 1994. Effects of artificial feed protein content on the growth of carp fish seed (OsphronemusgouramyLacepede) (Thesis). Bogor (ID): Institut Pertanian Bogor.

Basahudin, S. 2009. Harvest Moon Lele 2.5. PenebarSwadaya .Jakarta, 105 p.

Brett, J.R. and T.D.D, Groves. 1979. Physiological Energetics. pp: 279 - 351. In. W.S. Hoak, D.J. Randall and J.R. Brett. (Eds). Fish Physiology. Vol. VIII. Academic Press. New York, San Francisco.

Cahyono, B. 2001.Raising fish in public water. Publisher Canisius, Yogyakarta.

Effendie, M. 1979. Method I. Fisheries Biology.Yayasan Dewi Series.Bogor, 97 p. 
Effendie, M. and Y.I Hadiroseyani. 2002. Improved Survival Fish Larvae Betutu, Oxyeleotrismarmorata (Blkr.) With antibiotics. Journal of Aquaculture Indonesia Vol 1 (1): 9-13.

Francis G, Makkar HPS, Becker K. 2001. Factors Presentantinutritional in Plant-Derived Alternate Fish Feed Ingredients and Their Effects in Fish: Review article. Aquaculture 199: 197-227.

Halver, J. E. 1989.Fish Nutrition.Academic Press, Inc. California, pp 113-149

Handajani, and Widodo, Wahju. 2010. Fish Nutrition. Muhammadiyah University Press.Poor. $271 \mathrm{p}$

Inara C. 2011. Assessment cake flour rubber (TBBK) (Heveabrasiliensis) as a raw material for feed seed carp (Cyprinuscarpio) Linn.(Thesis). Bogor (ID): Institut Pertanian Bogor.

Karmini, M. 1996. Activity of Hydrolytic Enzymes Kapang Ryzopussp.At Tempe Fermentation Process. Centre of Research of development of Nutrition and Food NIHRD.

Khairuman and K. Amri. 2011. Book Smart Aquaculture 15 Fish consumption. Agromedia Pustaka, Jakarta, 112 p.

Ministry of Marine and Fisheries. 2014. Marine Fisheries Statistics 2014 Jakarta: MMF RI. $301 \mathrm{p}$.

Kordi, M, G.H. 2010. Business Opportunities And Catfish Cultivation Techniques Sangkuriang. PT. Gramedia Pustaka Utama. Jakarta, $195 \mathrm{p}$

Murtati, N.K.T. 1989. Use of Various Materials AttractanIn Artificial Feeds on Growth Tiger Shrimp (Paneusmanodonfabricus). (Thesis). Faculty of Animal Science Diponegoro University. Semarang.

Parakkasi, A. 1990.Science of Nutrition and Food Monogastric Animals. Publisher Angkasa. Bandung.
Poesponegoro, M. 1975. Food Fermentasi. Ceramah Scientific Results LKN-LIPI. Bandung.

Puri, E. 2011. Effect of Addition Dregs Coconuts Aspergillusoryzae Fermentation To Growth In Commercial Feed Tilapia (Oriochromiusniloticus) (Thesis). Department of Biology.State University of March. Surakarta.

Rakhmawati and Indariyanti, N. 2013. Nutritional Quality Improvement Waste Fruit Leather Cocoa and Leucaena Leaf through fermentation as Basis Protein Feed Tilapia. Journal of Applied Agricultural Research. 13: 108-115.

Rasyaf, M. 1989. Breeding Broiler.Publisher Sower Self Reliance. Jakarta. 189 p

Steel, R.G.D. and J.H. Torrie. 1989. Principles and Procedures of Statistics. Second Edition. PT. Gramedia. Jakarta.

Suprayudi MA. 2010. Local Raw Materials: Challenges and Expectations of Future Aquaculture (Abstract). Proceedings of the National Symposium on Biotechnology Aquaculture III October 7, 2010. BDP, FPIK, IPB. $31 \mathrm{p}$.

Suyanto SR. 2007.Cultivation of Catfish.Revised Edition.Sower Self Reliance. Jakarta.

Veni, F.V. 2007. Provision flour mixture and Fungus Rhizopussp Tubifexoligosporus As Artificial Larvae feed Gurame( Osphronemusgouramy Lac ) 10 Day -40. (Thesis).Faculty of Fisheries and Marine Sciences University of Bung Hatta.Field.

Yurnita, R. 2004. pemamfaatan Kernel Oil Cake With Different percentages Feed To Growth In Goldfish ( Cyprinuscarpio L ). (Thesis).Faculty of Fisheries and Marine Sciences, University of Bung Hatta.Field. 